\title{
The ECOWAS Court and the Politics of Access to Justice in West Africa
}

\author{
Adewale Banjo*
}

\begin{abstract}
Although the creation of the ECOWAS Community Court of Justice (ECJ) was approved in 1991 in pursuant to the provisions of Articles 6 and 15 of the 1993 Revised Treaty of the Economic Community of West African States, it was only set up a decade later in 2001. By utilising a content-analysis method, in addition to extensive personal interviews with the President of the Court, this study describes the emergence, composition, vision and competence/jurisdiction of the ECJ. The paper probes the various challenges currently faced by the ECJ, which include among others, logistics, limited public awareness among ECOWAS citizens, and non use by member states. The inability of ECOWAS citizens to access justice is given prominent emphasis with reference to the case of Afolabi Olajide vs. Federal Republic of Nigeria. The case typifies the extent to which the ECJ's establishment fulfilled or failed to meet the expectation of ECOWAS citizens' quest for justice. The study's conclusion examines current efforts at broadening access to the court for citizens of the community.
\end{abstract}

\section{Résumé}

Bien que la Cour de Justice Communautaire de la Cedeao ait été approuvée depuis 1991, elle n’a été mise en place qu’en 2001 - c’est-à-dire une décennie plus tard. Sa création fait suite aux dispositions des Articles 6 et 15 du Traité Révisé de la Communauté économique des États de l'Afrique de l'Ouest de 1993. En utilisant une méthode basée sur l'analyse du contenu, en plus des longs entretiens individuels avec le Président de la Cour, cette étude analyse l'émergence, la composition, la vision et la compétence/juridiction de la Cour. Ce papier examine les difficultés que la Cour a connues et continue de connaître. Celles-ci comprennent entre autres la logistique, l'absence de prise de conscience, et le manque de soutien de la part des États membres, de même que

* Dr Adewale Banjo is Associate Professor of Political Science at the University of Zululand, KwaZulu-Natal, South Africa. 
l'incapacité des citoyens de la Communauté à obtenir justice à travers la Cour. L'incapacité pour les citoyens de la Communauté d'avoir accès à la justice est mise en exergue à travers l'affaire qui a opposé Afolabi Olajide à la République Fédérale du Nigeria. Au regard de cette affaire, cet article permet de voir à quel point la mise en place de cette Cour permet de répondre ou non aux attentes des citoyens de la Communauté en matière d'accès à la justice. La conclusion de cette étude examine les efforts visant à assurer un accès plus significatif des citoyens à la Cour et les attentes par rapport à cette Cour.

\section{Introduction}

It is important to appreciate the fact that the Economic Community of West African States (ECOWAS) is one of the most dynamic sub-regional organisations in Africa. In fact, the United Nations Secretary General, Kofi Annan, through his Special Representative for West Africa, Mr. Ahmedou OuldAbdalah, has described ECOWAS as 'one of the most advanced sub-regional groups in the developing world’ (http://www.allafrica.com). Arguably, the transformation that has taken place by means of additional institutions and the revision of the ECOWAS Treaty since 1975 is a clear indication of this reality. The more so that a cursory look at the history of ECOWAS suggests that, apart from the fact that there have been a number of additional institutions, attempts have been made to broaden the economic agenda to include the political dimension in the integration process in West Africa. The inclusion of political security dimensions as a major part of the transformation process in ECOWAS has been explored in some works (see Adeleke 1995; Adeniji 1997; Gambari 1991; Aning 1994; Adekeye 2002; Vogt 1992; and Ofuatey-Kodjo 1994). But there has not been any major academic focus on the ECOWAS Court of Justice (ECJ) as a key institution, and which attempts to examine both its role and the character of the politics of access to the institution. The significance of this study is therefore predicated on the gap in the literature vis-à-vis the emergence and politics of access to the ECJ by West African citizens. The purpose of the study is to establish how the ECJ as an additional institution has evolved as part of the transformation process within the structure of ECOWAS. The paper highlights how the problems of lack of awareness by the Community citizens, non-patronage by the states, and inaccessibility to the Community citizens have become problems and how they are being resolved.

The study adopts the personal interview method of data collection and content-analysis of relevant media/official publications. The informal interviews were conducted from 9-11 December 2004. The study adopts the histo-sociological approach. Yet this is an empirical-analytical study that focuses on a contemporary case study set within the background of ECOWAS 
history. This approach helps to take advantage of the benefit of West African history and diplomatic relations in the way they have unfolded and interacted over time.

In terms of organisation, the paper is divided into eight sections, starting with an introduction pointing to the paper's significance, purpose, methodology and organisation of study. The second section deals with the background and brief history of ECOWAS, while the third section describes the emergence of the ECOWAS Court of Justice. The fourth deals with the composition, vision/mission, competence and jurisdiction of the Court .The fifth section deals with the challenges facing the Court. The sixth section narrates the facts and the argument in the case of one Afolabi Olajide vs. Federal Republic of Nigeria. This substantive empirical case has been given the widest possible analysis, to underscore the importance of this case in the transformation of the ECJ from a state-centric to a citizen-friendly institution. The seventh section describes the pressures and then the plans to accommodate the issues of human rights as well as accessibility to the Court by private citizens within the Community. The eighth section consists of a summary and some concluding remarks.

\section{Background}

Since attaining independence, African leaders have seen regional integration and cooperation (RIC) as a way to replace links with former colonial countries. RIC was considered to be crucial in attaining economic development, promoting regional stability, and guaranteeing African influence in international negotiations (Onwuka 1982). The 1960s and 1970s saw the emergence of many regional organisations in Africa, but sadly few have produced tangible results. The longstanding recognition of the needs and benefits of regional integration has spawned the proliferation of regional economies and protocols across the continent (Senghor 1990; Onwuka and Sesay 1985; Foroutan 1993).

In West Africa there are about 40 Intergovernmental Organisations (IGOs), some of which have their origins in the colonial past. Most of them are subject-specific or represent loose forms of regional cooperation, but there are also three economic communities, each pursuing the economic integration of its member countries. The first of these to be established was the Communauté économique de l'Afrique de l'Ouest (CEAO) in 1962, which succeeded a much older customs and economic grouping, the Union douanière et économique de l'Afrique de l'Ouest (UDEAO), covering several states in francophone west Africa. This regional body grew to be the Union économique et monétaire Ouest Africaine (UEMOA) currently grouping Benin, Burkina Faso, Côte d’Ivoire, Guinea Bissau, Mali, Niger, Senegal, and Togo. The 
other economic communities are the Mano River Union (MRU), established in 1973, and the Economic Community of West African States (ECOWAS), formed in 1975 (Bach 1993; Diop 1994; Onwuka 1982; Gowon 1984).

The Treaty of Lagos establishing ECOWAS was signed on 28 May 1975, by 15 member states made up of the following: Benin, Burkina Faso, Cape Verde, Côte d'Ivoire, The Gambia, Ghana, Guinea, Guinea Bissau, Liberia, Mali, Niger, Nigeria, Senegal, Sierra Leone, and Togo. Cape Verde joined in $1977 .{ }^{1}$

As stated in its founding Treaty, ECOWAS aims to promote cooperation and integration, leading to the establishment of an economic union in West Africa in order to raise the living standards of its people. It is also to maintain and enhance economic stability, foster relations among Member States and contribute to the progress and development of the Africa continent.

The fundamental principles of ECOWAS are: (a) Equality and inter-independence of Member States; (b) Solidarity and collective self-reliance; (c) Inter-state cooperation, harmonisation of policies and integration of programmes; (d) Non-aggression between Member States; and (e) Maintenance of regional peace, stability and security through the promotion and strengthening of good neighbourliness.

Other aims include: (f) Peaceful settlement of disputes among Member States, active cooperation between neighbouring countries and the promotion of a peaceful environment as a prerequisite for economic development; (g) Recognition, promotion and protection of human and people's rights in accordance with the provisions of the African Charter on Human and People's Rights. Further principles include: (i) Accountability, economic and social justice and popular participation in development; (j) Recognition and observance of the rules of principles of the Community; and (k) Promotion and consolidation of a democratic system of governance in each Member State (http:/www.ecowas.int/profile).

With regard to structure, the Economic Community of West African States is organically and administratively structured thus: (a) The Authority of Heads of State and Government; (b) The Council of Ministers; (c) The Community Parliament; (d) The Community Court of Justice; (e) The Economic and Social Council; (f) The Executive Secretariat; (g) The Fund for Cooperation, Compensation and Development; (h ) A specialised agency of ECOWAS, the West African Health Organisation (WAHO), and any other institutions that may be established by the Authority (http://www.ecowas.int/profile).

A revised ECOWAS Treaty designed to accelerate economic integration and to increase political cooperation, was drafted in 1991-92, and was signed in July 1993. The ECOWAS Revised Treaty designates the achievements of a common market and a single currency as economic objectives. In the political sphere it envisages the establishment of a West African Parliament, 
an economic and social council and an ECOWAS Court of Justice, to replace an existing Tribunal to enforce Community decisions.

It is against this background that this article takes a critical look at the ECOWAS Court of Justice in both conceptual and historical context; undertaking a specific analysis of the court, identifying its challenges, and its transformation from a state-centred to a people-centred institution.

\section{The Community Court of Justice}

Of the over 40 international permanent judicial and quasi-judicial courts, at least 15 are in Africa. Of these fifteen, two exercise criminal jurisdiction. These are the International Criminal Tribunal for Rwanda (ICTR), and the more recent Special Court for Sierra Leone. Other regional courts of justice include the Courts of Justice of the Common Market of East and Southern Africa (COMESA). There is also the East African Community (EAC), the Union Economique et Monétaire Ouest-Africaine, the Tribunal of the Southern African Development, and the ECOWAS Court of Justice.

The Community Court of Justice was established in 1991 and, with the Revised Treaty of the Community, came into existence in 1993. The Protocol on the Community Court of Justice was signed on 6 July 1991 in Abuja, Nigeria, and the Protocol entered into force on 5 November 1996. The Protocol A/P1/7/91 on the Community Court of Justice was ratified as follows: 02/11/00, 01/12/99, 28/08/97, 16/02/96, 05/11/96, 01/07/94, 30/06/94, 07/ 12/92, 18/07/92 and 23/05/92.

\section{Composition and vision of the Court}

The Members of the ECOWAS Community Court of Justice were sworn in as Justices of the Court on 30 January 2001 in Bamako, Mali before his Excellency, Alpha Omar Konare, then President of Mali and Chairman of the Authority of the Heads of States and Government of ECOWAS.

According to the President of the Court, '... following the inauguration of the court... the first task we were faced with was the preparation of the Rules of Procedure based on the Protocol of the Court. This was quickly executed and submitted to the Council of Ministers of ECOWAS and was approved...' (Justice H.N Donli: Personal Interview, 10 December 2004.)

The Court is composed of seven Honourable Members drawn from the Member States of ECOWAS. The judges are:

Justice Hansine N. Donli (Nigeria), President

Justice Souman Dirarou Sidibe (Niger), Vice-President

Justice Barthelemy Toe (Burkina Faso), Member

Justice Anthony A. Benin (Ghana), Member 
Justice Aminata Malle (Mali), Member

Justice Awa Daboya Nana (Togo), Member

Justice El-Mansour Tall (Senegal), Member.

In terms of gender, the ECOWAS Court of Justice has three women as members. These are Justices H.N. Donli, the President, Awa Daboya Nana and Aminata Malle. With reference to the region's linguistic blocs, the Anglophone countries are represented by Ghana and Nigeria, while the Francophone states are represented by Burkina-Faso, Mali, Togo and Senegal. There was no appointment made from Lusophone states. However, the non-representation of the Lusophone bloc does not indicate any deliberate attempt to exclude the Portuguese-speaking states from the activities of the ECOWAS Court of Justice. In fact, the Court, in accordance with Article 31 of the protocol and Article 87 of the 1993 Revised Treaty, retained English, French and Portuguese as its official languages. Furthermore, the protocol provides inter alia that 'the Court shall be composed of the independent judges [members] selected and appointed by the Authority of the Head of States and Government from nationals of the member states' (The ECOWAS Court - Annual Report 2003).

The protocol further provides that the Court shall consist of seven members and shall elect a president and vice-president from among their member. $^{2}$ With reference to the professional competence and experience of the judges appointed, they have been described as 'highly experienced and distinguished judges’ (AU Magazine, December 2004-February 2005, Vol.1. Issue 2, 2004). The President of the Court noted during an interview that: 'The Court is indeed fortunate to have a crop of judges who have outstanding legal careers and have contributed immensely in their various countries to the legal profession' (Justice H.N. Donli, Personal Interview: 10 December 2004).

As soon as the Court commenced preparation for its take off, the vision and mission were set out. These included:

(a) Encouragement of fundamental Human Rights observance. To achieve this, the Court will undertake a process of creating awareness among the populace of Member States regarding the existing Treaties among the Member States and the fact that individuals can have access to the Court through their Member States if they feel aggrieved.

(b) Encouragement of the Member States to amicably settle disputes among themselves through alternative dispute resolution processes. 
(c) Harmonisation of relationships with relevant International Organisations such as the European Community Court of Justice, the International Court of Justice and other International Institutions.

(d) Speedy dispensation of justice, dissemination of information, easy access to proceedings and the judgements of the Court. A fast-track procedure that is already being applied in other areas of the Community would be utilised (Information Manual, Community Court of Justice: July 2001).

\section{Competence of the Court}

The decision of the Court shall be binding on the Member States, the Institutions of the Community and on individuals and corporate bodies. With reference to the competence of the Court, Article 9 of the Protocol on the Community Court of Justice stated that:

(a) The Court shall ensure the observance of the law and of the principles of equity in the interpretation and application of the provisions of the Treaty;

(b) The Court shall also be competent to deal with disputes referred to it in accordance with the provisions of Article 36 of the 1993 Revised Treaty, by Member States or the Authority. When such disputes arise between the Member States and Institutions of the Community, on the interpretation or application of the provisions of the Treaty;

(c) A Member State may, on behalf of its nationals, institute proceedings against another Member State relating to the interpretation and application of the provisions of the Treaty. The Court shall have any powers conferred upon it specifically by the provisions of this Protocol (Justice H.N. Donli 2003: 14). It is important also to observe that the protocol provides for amendments of the provisions of the protocol and rules of procedure.

\section{Jurisdiction of the Court}

On the account of Article 9 of the protocol, the jurisdiction and rights of access to the Court are well established. The jurisdiction of the Court is prescribed by the provisions of Articles 76(2) of the 1993 Revised Treaty and Articles 9 and 10 of the protocol of the Court. The primary function of the Court is the interpretation and application of the ECOWAS Treaty and the Protocols and Conventions annexed thereto (The Rules of the Community Court of Justice: 2002).

Under the provisions of Article 76(1) of the 1993 Revised Treaty any dispute regarding the interpretation or the application of the provisions of the Treaty shall be amicably settled by the parties and it is only where this fails that either party or any other Member State or the Authority may under Article 76(2) of the Treaty refer the dispute to the Court. Article 9(2) of the 
Protocol further provides that the Court shall be competent to deal with disputes referred to it in accordance with the provisions of the Treaty by Member States or the Authority when such disputes arise between the Member States or between one or more Member States and the institutions of the Community on the interpretation and application of the provisions of the Treaty. Under Article 9(3) of the Protocol a Member State may, on behalf of its nationals, institute proceedings against another Member State or Institution of the Community, relating to the interpretation and application of the provisions of the Treaty, after attempts to settle the dispute amicably have failed.

The Authority of the Heads of State and Government, may under the provisions of Article 7(3)(g) of the Revised Treaty, refer where it deems necessary any matter to the Court when it confirms that a Member State or Institution of the Community has failed to honour any of its obligations or an Institution of the Community has acted beyond the limits of its authority or has abused the powers conferred on it by the provisions of the Treaty, by a decision of the Authority or a regulation of the Council.

Under Article 10 of its Protocol, the Court may, at the request of the Authority, Council, one or more Member States, or the Executive Secretary and any other Institution of the Community, express in an advisory capacity a legal opinion on questions of the Treaty. The Authority of the Heads of State and Government may also, under Article 7(3) (h) of the Revised Treaty, request the Court to give advisory opinion on any legal questions.

From the foregoing, it has become obvious that the ECOWAS Court of Justice is to function as the principal legal/decision-enforcing organ of the community. The essential role of the Community Court of Justice is to ensure the observance of law and justice in the interpretation and application of the Treaty, the Protocols and Conventions. The Court is awarded the responsibility for settling such disputes as may be referred to it in accordance with the provisions of Article 56 of the Treaty and disputes between states and the Institutions of the Community and other functions as ascribed by Article 76 of the 1993 Revised Treaty (Justice H.N. Donli, 2003:14).

\section{Challenges to the Court}

The President of the Court provided an insight into some primary challenges that were faced and still facing the ECOWAS Community Court of Justice, since its inauguration in 2001.

(i) Logistics: The first of such challenges is the fact that 'the Authority of ECOWAS was not decided on the Permanent Seat of the Court even after the Court was approved or established in principle...it became obvious 
this was a major challenge, imagine heading an institution without a base' (Justice H.N. Donli, Personal interview, 10 December 2004).

However, the President described how she was able to secure the temporary seat for the Court at the National Assembly Building, Tafawa Balewa Square, in Lagos, Nigeria. This building housed the Court until there was a decision on the permanent location of the Court. Thereafter the Court moved to Abuja. The decision to move the seat of the Court to Abuja came with the nomination of Nigeria as the permanent host country of the Court and of the ECOWAS Parliament. This decision was taken at the 2002 Summit of the organisation in Dakar, Senegal [www.nigeriaembassyusa.org].

According to the President, 'on getting to Abuja, we started tackling problems of infrastructure like the courtroom, offices and residences for the judges. We were fortunate to receive the cooperation of all concerned. We have this edifice as the office complex and the courtroom. All the judges are accommodated in their residence. It was not an easy task at all, having a new institution, which was pre-conceived in 1991, without any structure whatsoever, and then having to put all that on the ground and start hearing cases... ' (Justice H.N. Donli, Personal Interview, 10 December 2004).

(ii) Limited Awareness: There is generally a lack of awareness even by the states, in relation to the services the Court could provide. According to the President, '.. We have been trying to create awareness in Member States about the need to seek such advice with respect of the different problems they will be facing, arising from interpretation of the Treaty and Protocols. As a result of lack of awareness about the services and competence/capacity of the Court and partly because of the newness of the Court, the Court is underutilised (Ibid). The President in fact lamented that 'We have not handled many cases because ours is relatively a new court. By Article 10 of the Protocol, Member States may seek legal advisory opinion. The Member States are yet to apply or seek such advice...' (AU Magazine, 2004: 19).

This mechanism was incorporated in the Court's Protocols so as to avoid conflicts and war amongst Member States. They are beginning to understand that there is a possibility of the Treaty, Protocols and Community Statutes being either misinterpreted or misunderstood, which could lead to conflict. Surely, the Community is not interested in adding to the basin of conflict that has become the lot of the African. Hence the Court is enjoined to observe international law, and to apply it to all cases that 
come before it in respect of the 1993 Revised Treaty and Protocols of the Community.

(iii) Non Use by the states and non-direct access by citizens continue to plague the court. But despite the comprehensive provisions for the states, the President of the Court during an interview expressed surprise that the states have not thought it necessary to make full use of the services of the Court, as provided for in the Treaty and Protocols. In fact no legal opinion has been sought so far, and no case has been brought before it by any state in the sub-region.

At this juncture it is important to reflect on the worries of the President visà-vis the inability of the citizens to access the Court directly. According to the president, 'We are concerned that the Revised Treaty and the Protocol of the Court did not give nationals of the Member States direct access to the Court. In other words the parties that come before the Court are institutions, Member States, the Authority of Heads of States, the Council of Ministers and so on. Individuals may come before the Court, if they have grievances relating to the Revised Treaty and Protocols or matters arising from the same, through the Member States. It means the individuals may not have direct access to the Court, except through their country. This is why, in the first case that came before the Court, it decided that an individual may not file an action directly to the Court except through his Member State'. (Justice H.N. Donli, Personal Interview, 10 December 2004).

The following section is therefore an attempt to appraise the legal battle that arose in the case brought before the Court by Mr Afolabi Olajide against the Federal Republic of Nigeria in 2003.

\section{The First Case: Mr. Afolabi Olajide vs. Federal Republic of Nigeria}

As stated earlier, under the provisions of the Revised Treaty and the Protocol of the Court, only Member States and Institutions of ECOWAS have direct access to the Court. But the very first case to be brought before the Court was by a private individual, Mr. Afolabi Olumide (as Plaintiff) versus the Federal Republic of Nigeria (as Defendant). The subject matter of the proceedings focused on:

(i) Closure of border and restriction to Free Movement of persons and goods, Right of ingress and egress to and fro from the Federal Republic of Nigeria into and out of the Republic of Benin by the Nigerian Government.

(ii) Violation of the Plaintiff's right to Free Movement of his person and goods as enshrined in Article 12 of the African Charter on Human and 
Peoples’ Rights (Ratification and Enforcement) Act, Laws of the Federation of Nigeria, 1990.

(iii) Human Factors militating against Free Movement of Persons and goods by the erection of toll-gates by the Nigerian Government and collection of illegal toll fares by officers and men of the Nigerian Custom Service and Immigration Officials (Community Court of Justice - 004/ECW/CCJ/04:6).

The narration of the facts by the plaintiff was as follows:

(a) The plaintiff avers that he is an ECOWAS citizen and a businessman, who travels regularly by road through Seme border to and from the Republic of Benin to buy goods for sale in Nigeria.

(b) The plaintiff avers that in furtherance of his business he had made plans to travel to Benin Republic to buy goods on 9 August 2003. Having made contact with his customers to arrange for some consignments of goods for him, to enable him return to Nigeria the following day, i.e. 10 August 2003 but not later than 11 August 2003.

(c) The plaintiff avers that on Saturday 9 August 2003, the Federal Government of Nigeria announced the immediate closure of her border with her Western neighbour, Benin Republic.

(d) The plaintiff avers that the closure was without prior notice, and having attempted to travel to Benin Republic without prior information, he was restrained and refused by Nigerian law enforcement agents the right of passage into Benin Republic to take delivery of his goods.

(e) The plaintiff avers that apart from losses by way of gains he would have made from sales of the goods if he were permitted, he is being asked by the customers in Benin Republic to pay for the goods already arranged for him as they were denied the opportunity of selling the goods to other customers.

(f) The plaintiff avers that the closure of the border by the Federal Government of Nigeria is a violation of the Terms of the Protocol for free movement of persons and goods within the region narration of facts by the plaintiff, he then asked the Court on 10 contained in the 1993 Revised Treaty of the Economic Community of West African States (ECOWAS), 1993, and the Protocol on Free Movement of Persons and Goods (Community Court of Justice-2004/ECW/CCJ/04:9).

After the submission of the October 2003 to declare that:

(i) The unilateral closure by the Federal Republic of Nigeria of her border with the Republic of Benin from 9 to 15 August 2003, is unlawful and 
breach of Article 3(2)(d)(iii) and article 4(g) of the Treaty of the Economic Community of West African States (ECOWAS) dated 24 July, 1993, and to which Nigeria is a signatory.

(ii) The closure by the Federal Republic of Nigeria of her border with Benin Republic from 9 to 15 August 2003, is a violation of the plaintiff's right to Free Movement of his person and goods, Rights of egress and ingress as guaranteed by the revised Treaty of the Economic Community of West African States, 1993, the Protocol on the movement of persons and goods, and article 12 of the African Charter on Human \& People's Rights adopted by the Federal Republic of Nigeria in 1990.

(iii) A mandatory order of injunction restraining the Federal Republic of Nigeria from further closure of her border with Benin Republic.

(iv)Costs of 5,000,000 Nigerian Naira (about \$37,000) against the Defendant (Community Court of Justice-2004/ECW/CCJ/04:11).

\section{Defendant's preliminary objection}

The Department of International and Comparative Law, at the Federal Ministry of Justice in Abuja on behalf of the Federal Government of Nigeria responded by objecting on the ground that the Court lacked the jurisdiction or the competence to entertain the suit. The Nigerian government based its objection on the facts that:

(a) 'The provisions of Article 9 of Protocol A/P.1/7/91 on the Community Court of Justice govern the competence of the Court.

(b) The Court shall... be competent to deal with disputes referred to it, in accordance with the provisions of Article 56 of the Treaty, by Member States or the Authority, when such disputes arise between the Member States or between one or more Member States and the institutions of the Community on the interpretation or application of the provisions of the Treaty'.

(c) A Member State may, on behalf of its nationals, institute proceedings against another Member State or institution of the Community, relating to the interpretation and application of the provisions of the Treaty after attempts to settle the dispute amicably have failed.

(d) Thus, it is only a Member State that can take a matter to the Court either on its behalf or on behalf of its nationals. This suit was not instituted by a Member State.

(e) The plaintiff/respondent has no right of direct access to the Court. 
After presenting the above preliminary objections, the defendant then sought an order striking out the suit for want of jurisdiction, and such further order or other orders as the Court may deem fit to make in the circumstances (Community Court of Justice-2004/ECW/CCJ/04:17).

\section{Reply to defendant's notice of preliminary objection}

In a statement dated 22 January 2004, in response to the defendant's notice of preliminary objection dated 27 November 2003, the plaintiff argued that 'the use of may in article 9(3) of the protocol A/P.1/7/91 is directory not mandatory'. The plaintiff also claimed that the provision of 'indirect access' contained in article 9(3) of the protocol A/P.I/7/91 would be applicable only where the Member State to which a Community citizen seeks to sue is not his own country.

The plaintiff on the strength of the new submission then sought for an order dismissing the preliminary objection dated 27 of November, 2003. He asked the Court to award the costs of 50,000 Nigerian Naira against the defendant, in addition to an order directing the defendant to file a Statement of Defence to the suit on its merit (Community Court of Justice-2004/ECW/ CCJ/04:23).

\section{Defendant's/Applicant's brief in support of preliminary objection to the jurisdiction of the court}

In yet another Defendant/Applicant's brief in support of a preliminary objection to the jurisdiction of the Court, the Federal Government of Nigeria on 9 February 2004, argued that only the Member States, the Authority of Heads of State and Government, and a Member on behalf of its nationals have right of access to the Community Court. The defendant insisted that the Court has a duty to interpret Article 9 of the Court's protocol and Revised Treaty of ECOWAS as they stand, all perceived imperfections or shortcomings therein notwithstanding.

To the defendant, jurisdiction was statutory. The defendant further argued that where the enabling statute does not confer jurisdiction on a Court, the Court cannot confer jurisdiction on itself, no matter how desirable it may seem. 'The Courts are themselves creatures of statute and must not be seen to appear to grab jurisdiction which they may expound but not expand'. It cannot even be conferred by the agreement of parties or by acquiescence. By the provisions of protocol A/P.1/7/91 on the Community Court, this Court lacks jurisdiction to adjudicate on this suit, as the plaintiff/respondent cannot institute an action directly in the Court. The appropriate forum for the plaintiff/respondent to seek redress is not this Court, but should be the Nigerian Courts. This is because the Nigerian Constitution confers jurisdiction/power 
on the Nigerian Courts to entertain disputes relating to the Civil Rights and obligations of citizens. This Court does not have such blanket powers to adjudicate on disputes relating to the Civil Rights and obligations of Nigerian citizens. It can only adjudicate in line with the jurisdiction conferred on it by its Protocol. The defendant/applicant then urged the Court to strike out the plaintiff/respondent's suit for want of jurisdiction, with substantial costs (Community Court of Justice - 2004/ECW/CCJ/04:44).

\section{The judgment of the Court}

On 27 April 2004, after reviewing the facts of the case, the preliminary objection and the submission of counsel, the Court deliberated and examined all issues canvassed by parties. In addition to the salient points in relation to the preliminary objection therein, the Court established its findings and further announced the grounds for the decision of the Court on this matter. The Court in an answer to the application for striking out the proceedings instituted by the applicant on 10 October 2003, granted the same. In the same circumstance, the preliminary objection was upheld based on the consideration that even though Article 9 (3) is not in pari materia with Article 34 of the International Court of Justice, the clear intendment excludes persons not mentioned therein.

According to the Court, after examining the argument of both learned counsels and the authorities regarding the issue, the Court decided that the issue before it is that of competence to adjudicate on the proceedings instituted by the applicant against the respondent and not on Locus standi per se, as the applicant's counsel contended vigorously before the Court. In the final analysis, opposition to the preliminary objection cannot stand. Consequently, the proceedings instituted by the applicant must fail (Community Court of Justice - 2004/ECW/CCJ/04:72).

With the assent of Justices Awa Daboya Nana and Aminata Malle, Justice Donli held: 'Finally, every provision of the Community law as a whole must be placed in its context and applied or interpreted in the light of the provisions of Community law as a whole, regard being had to the objectives thereof and to its states of evolution at the date on which the provision in question is to be applied' (ThisDay 28 April 2004).

\section{Accommodating citizens, amending the protocol}

In the case of Afolabi Olajide vs. Federal Government of Nigeria decided on 27 April 2004, it became clear that the limited scope of jurisdiction of the Court and the denial of access to the Court to individuals were grave and fundamental limitation to the rights of private West African individuals. Hence, the President of the Court, Justice Hansin Donli, after delivering the judg- 
ment, urged formulators of the Act to broaden its scope to enable individuals to bring actions before the Court as there are cases which Member States cannot bring on behalf of its nationals (Vanguard, 28 April 2004).

In its reaction to the judgment of the Court, Interights noted that, 'indeed the designated functions of the Court largely concern the interpretation of the ECOWAS Treaty, to which only states are parties. It was constructed to resolve issues of "traditional" international law - i.e. the rights and obligations of states toward each other - and as such has little need for individual access’ (http;//www.interights.org/news).

Furthermore, Interights observed that even human rights tribunals, which deal with the field of public international law that is most concerned with individuals, provide little opportunity for private plaintiffs to sue governments. In fact, of the major international human rights panels, only one, the European Court of Human Rights, allows individuals to sue, and that court has the advantage of (1) a reasonably cohesive regional federation with functioning institutions; (2) a uniform human rights charter that has been adopted as domestic law by the member states; and (3) member states that are willing to abide by its decisions (http://www.headheeb.blogmosis.com/archives/).

However, the newly established African Court of Human and People's Rights and the Inter-American Court of Human Rights do not have these advantages. This is because they operate in areas where regional integration is much weaker. As such, the ACHPR's jurisdiction is limited to states, and the IACHR instrument allows only indirect private access. Not surprisingly, the international courts that are friendly to individual litigants are those that deal with private international law, such as bodies created to arbitrate international commercial disputes.

In their reaction to the ECOWAS Court judgment, the participants at a Consultative Forum on protecting the Rights of ECOWAS Citizens through the ECOWAS Court issued a statement in which they stated that:

...It is hoped and expected that that as regional integration progresses, human rights tribunals are expected to become more accessible to individuals and NGOs, and more regional courts such as the ECOWAS Court might extend their jurisdiction to human rights matter (Declaration of the Participants at the Consultative Forum on protecting the Rights of ECOWAS Citizens through ECOWAS Court of Justice: 2003).

Indeed, the Afolabi vs Nigeria case and the judgment of the Court provoked an intense debate on the urgent need to amend the Court protocol with the sole aim of accommodating citizen's access to the court. On the advice of the judges of the ECOWAS Court, plans were instituted to adopt and ratify the Supplementary Protocol A/SP.1/1104 amending the preamble and articles 
1, 2, 9, 22 and 30 of ProtoclA/P.1/7/91 relating to the Community Court of Justice and paragraph 1 of the English version of the Protocol. This new proposed amendment guarantees the basic fundamental freedoms to ECOWAS citizens. The amendment recognises the promotion and protection of human and people's rights in accordance with the provisions of the African Charter on Human and People's Rights. Under the new supplementary protocol, article 9 of The Protocol Relating to the Community Court of Justice was deleted and has been substituted by a set of new provisions, which includes the provision of Article (9)(4)] which states that: 'The Court has jurisdiction to determine cases of violation of human rights that occur in any Member State' (Draft Supplementary Protocol, 2004).

However, without direct access to the Court it would be impossible for individuals to enforce these rights. Therefore, the decision by the Council to expand the powers of the Court and grant direct access to the Court to individuals is highly commendable. This feat was achieved during the TwentyEighth session of the Authority of Heads of State and Government in November 2004. According to the Supplementary protocol A/SP.1/11/04 amending the Preamble and Articles 1, 2, 9, 22 and 30 of protocol A/P.1/7/91 relating to the Community Court of Justice and Article 4 paragraph 1 of the English Version of the Protocol (Draft), the Protocol on the Community Court of Justice was amended by the insertion of the following new Article as follows:

Access to the Court is open to the following

(a) Member States, the Authority and unless otherwise provided in a protocol, the Executive Secretary, where action is brought for failure by Member States to fulfil an obligation;

(b) Member States, the Authority, the Council of Ministers, the Executive Secretary and any other institution of the Community in proceeding, for determination of the legality of an action in relation to any Community text;

(c) Individuals and corporate bodies in proceedings for the determination of an act or inaction of a Community official which violates the rights of the individuals or corporate bodies;

(d) Individuals on application for relief for violation of their human rights: the submission of application for which shall (i) not be anonymous; nor (ii) be made whilst the same matter has been instituted before another international Court for adjudication; 
(e) Staff of any Community institution, after the staff Member has exhausted all appeal processes available to the officer under the appropriate community texts.

(f) Where in any action before a Court of a Member State, an issue arises as to the interpretation of a provision of the Treaty, or the other Protocols or Regulations, the national Court may on its own or at the request of any of the parties to the action refer the issue to the Court for interpretation (Draft Supplementary Protocol 2004).

At this juncture, although the proposed amendment of the protocol on the Community Court of Justice is a welcome idea, it is important to recognise the fact that the process of ratification is subject to political considerations. It is therefore hoped that with the aid and assistance of civil society organisations, the Member States will be sensitised enough to facilitate this process of ratifying the Supplementary Protocol.

\section{Concluding remarks}

Though not envisaged in 1975 when ECOWAS was founded, the ECOWAS Community Court of Justice (ECJ), which was approved in 1991 and was set up in 2001 - a decade after - has become an additional institution for ECOWAS. Its establishment, which is pursuant to the provisions of Articles 6 and 15 of the revised Treaty of ECOWAS, has on one hand been commendable and on the other been fraught with a number of challenges. The challenges that have faced and are still facing the Court include logistics, lack of awareness, non-patronage by the states as well as inability of the Community citizens to obtain justice through the court. The inability of the citizens of the Community to access justice in the Court has been given prominent emphasis with reference to the case of Afolabi vs Federal Republic of Nigeria. This is to underscore the vital foundation this case has laid for the eventual transformation of the Court, from a state-centred to peoplecentred supranational institution.

In sum, the study has probed the extent to which the court has fulfilled or failed to meet the expectation of citizens of ECOWAS regarding access to justice, in addition to an examination of efforts at ensuring the broadening of citizen's access to the Court. Finally, it is hoped that the Court will evolve into a unique and essential body growing and matching up to international standards, not only in structure and infrastructure but also in the value and authoritative content of its judgments. It must be an institution where any party that files its case will still obtain justice, thereby ensuring peace and harmony in the sub-region. 


\section{Notes}

1. In December 1999, Mauritania announced that it would withdraw from ECOWAS as a result of its disagreement with some of the decisions taken at the summit.

2. The first President of the Court is a Nigerian legal luminary, Hon. Justice Hansine Napwaniyo Donli. The President has held several positions and has diverse experience in the field of law. The President was formerly the Kaduna State Attorney-General and Commissioner for Justice, having earlier served as the Kaduna State High Court Judge, before her appointment as the President of the Community Court of Justice. She has held offices in several legal bodies. Hon. Justice Donli has, in both a personal and official capacity, attended and participated in international conferences in Berlin, Seoul, and Barcelona. This is in addition to active participation in International Conference on the Law of War, International Conference on the Law of Evidence in Vancouver, Canada and International Conference of Experts on Criminal Law, Portland, USA. Hon. Justice H.N. Donli has been honoured with several accolades, including the award received from the European Court of Justice.

\section{References}

Adeleke, A., 1995, 'The Politics and Diplomacy of Peace-keeping in West Africa: The ECOWAS Operation in Liberia', Journal of Modern African Studies, 33, 4. Adeniji, O., 1997, 'Mechanisms for Conflict Management in West Africa: Politics of Harmonization,' ACCORD Occasional Paper.

Adekeye, A., 2002, Liberia's Civil War-Nigeria, ECOMOG, and Regional Security in West Africa, (A project of International Peace Academy), Boulder and London, Lynne Rienner Publishers.

Aning, E.K., 1994, Managing Regional Security in West Africa: ECOWAS, ECOMOG and Liberia, Copenhagen, Center for Development Research, Working Paper 94.2, February 1994.

AU Magazine, December 2004-February 2005, Vol 1.Issue 2, 2004, pp.18-20.

Bach, Daniel, 1983, 'The Politics of West African Economic Cooperation: CEAO and ECOWAS', Journal of Modern African Studies, 21, 4.

Community Court of Justice, 2001, Information Manual.

Community Court of Justice, 2002, The Rules of the Community Court of Justice (ECOWAS), 3 June, Abuja.

Community Court of Justice of The Economic Court of West African States, 2004, Mr Afolabi Olajide Vs. Federal Republic of Nigeria, Judgment Delivered 27 April, 2004, Abuja, Nigeria, (Citation 20004/ECW/CCJ/04).

Declaration of the Participants at the Consultative Forum on protecting the Rights of ECOWAS Citizens through ECOWAS Court of Justice, 2003.

Diop, M.C, and Lavergne, R.,1994, Regional Integration in West Africa, Proceedings of the International Conference organised by IDRC in Dakar, Senegal,11-15 January 1993. Ottawa: International Research Development Center. 
Donli, H.N., 2003, Community Court of Justice - Annual Report, 2003.

Draft of the Supplementary Protocol A/SP.1/11/04 amending the Preamble and articles 1, 2, 9, 22 and 30 of protocol A/P.1/7/91 relating to the Community Court of Justice and Article 4 paragraph 1 of the English Version of the Protocol, 2004.

Foroutan, F., 1993, 'Regional Integration in Sub-Saharan Africa: Past experiences and future and future prospects', in de Melo, J. and Panagariya, A. eds., New Dimensions in Regional Integration, Cambridge: Cambridge University Press. Gambari, I., 1991, Political and Comparative Dimensions of Regional Integration: The Case of ECOWAS, London: Humanities Press International.

Gowon, Y., 1984, 'The Economic Community of West African States: A Study of Political and Economic Integration', PhD Thesis, Warwick University.

http://www.interights.org/news 'Interights latest news - individuals to be given direct access to the ECOWAS Court of Justice’, (Accessed 22/12/2004).

http://www.ecowas.int/ profile, (Accessed 22/12/2004).

http://www.nigeriaembassyusa.org. (Accessed 22/12/2004).

http://www.allafrica.com. (Accessed 10/2/2005).

http://www.headheeb.blogmosis.com/archives/, (Accessed 22/12/2004).

Ofuatey-Kodjoe, W., 1994, 'Regional Organizations and the Resolution of Internal Conflicts: The ECOWAS Intervention in Liberia', International Peace-Keeping, 1,3 .

Onwuka, R., and Amadu, S., eds., 1985, The Future of Regionalism in Africa, London: Macmillan.

Onwuka, R., 1982, Development and Integration in Africa: The Case of the Economic Community of West Africa States, Ile-Ife: University of Ife Press.

Senghor, J.C., 1990, 'Theoretical Foundations for Regional Integration in Africa: An Overview', in Peter Anyang Nyong'o, ed., Regional Integration in Africa: Unfinished Agenda, Nairobi: African Academy of Sciences, 17-34.

ThisDay, 2004, 'ECOWAS Court not open to individual litigants', 28 April. Vanguard, 2004, 'ECOWAS Court throws out suit against Nigeria', 28 April. Vogt, M.A., ed., 1992, The Liberian Crisis and ECOMOG: A Bold Attempt at Regional Peace-Keeping, Lagos: Gbajumo. 
